JLJ 9 (2)(2020)
Jttp://journal.unnes.ac.id/sju/index.php/jlj

\title{
MEDIA KARTU KUARTET DIKDA SENI TARI BERBASIS OUTDOOR LEARNING
}

\section{Siti Eva Ariyanti ${ }^{\varpi}$, Deasylina da Ary}

Jurusan Pendidikan Guru Sekolah Dasar, Fakultas Ilmu Pendidikan, Universitas Negeri Semarang, Indonesia

\section{Info Artikel}

Sejarah Artikel:

Diterima April 2020

Disetujui Mei 2020

Dipublikasikan Juni

2020

Keywords: learning media; quartet card DIKDA; outdoor learning; dance education

\begin{abstract}
Abstrak
Dalam seni tari, guru kelas II SD Negeri 03 Bawu diketahui belum menggunakan media pembelajaran yang inovatif, sehingga diperlukan media yang inovatif dalam pembelajaran. Penelitian ini bertujuan untuk mengembangkan media kartu kuartet DIKDA seni tari berbasis outdoor learning pada materi gerak keseharian dan alam. Untuk mengembangkan media tersebut digunakan penelitian Research and Development (R\&D) diadaptas dari Sugiyono. Penelitian ini diikuti oleh siswa kelas II SD Negeri 03 Bawu berjumlah 41 siswa. Teknik analisis data meliputi analisis data produk, analisis data awal, dan analisis data akhir berupa uji t-tes dan uji n-gain. Hasil pengembangan media kartu kuartet DIKDA Seni Tari berbasis outdoor learning sangat layak digunakan dengan memperoleh hasil persentase sebesar $96,88 \%$ oleh ahli media, 96,88\% oleh ahli materi dan $93,75 \%$ oleh ahli bahasa. Dari hasil skala kecil tanggapan siswa terhadap media sangat baik dengan persentase $100 \%$ dan $92 \%$ dari tanggapan pada skala besar mendapatkan persentase $97,9 \%$ dari siswa dan $100 \%$ dari guru. Hasil uji peningkatan rata-rata diperoleh hasil sebesar 0,567 pada skala kecil dan 0,466 pada skala besar. Simpulan penelitian media kartu kuartet DIKDA Seni Tari berbasis outdoor learning materi gerak keseharian dan alam layak dan efektif dalam meningkatkan hasil belajar psikomotorik siswa kelas II Sekolah Dasar.
\end{abstract}

\section{Abstract}

In dance education, in the second grade of Bawu 03 elementary school had not used innovative learning media, so that media development was needed in learning. This research aimed to develop, to find out the results of feasibility, and test the effectiveness of DIKDA quartet cards on dance education based on outdoor learning on daily and natural motion material. The type of this study was Research and Development $(R \& D)$ adapted from Sugiyono's theory. The participants of this study were the second grade at Bawu 03 elementary school in the number of 41 students. Data analysis techniques included product data analysis, initial data analysis, and final data analysis in the form of $t$-test and $n$-gain test. The results showed that learning media in the media of DIKDA quartet cards on dance education based on outdoor learning was very feasible to use by obtaining a percentage of $96,88 \%$ by media experts, $96.88 \%$ by material experts and $93,75 \%$ by language experts. The results of small scale got a percentage of $100 \%$ of students and $92 \%$ of teachers and on a large scale get a percentage of $97,9 \%$ of students and $100 \%$ of teachers. The results of the test large scale got on average obtained results of 0.567 on a small scale and 0.466 on a large scale. The conclusion of this research was the media of DIKDA quartet cards on dance education based on outdoor learning on daily and natural motion material was feasible and effective in improving students psychomotor learning outcomes in the second grade.

(C) 2020 Universitas Negeri Semarang

Alamat korespondensi:

ISSN 2252-6366

Bringin, RT. 09/RW.03, Batealit, Jepara

E-mail: eva_sitievaariyanti@yahoo.co.id 


\section{PENDAHULUAN}

Pendidikan merupakan tiang kebudayaan dan pondasi utama untuk membangun peradaban bangsa. Kesadaran arti penting pendidikan akan menentukan kualitas kesejahteraan negara dan masa depan warganya. Oleh karena itu, pendidikan di Indonesia berpegang pada salah satu tujuan bangsa Indonesia yang tertera dalam pembukaan Undang-undang Dasar 1945 alenia ke empat yaitu mencerdaskan kehidupan bangsa. Namun, kenyataan di lapangan tidak sesuai dengan yang diharapkan. Kualitas pendidikan di Indonesia masih jauh dari cakupan baik. Guru berkewajiban untuk mewujudkan pembelajaran yang efektif agar dapat mencapai tujuan pendidikan nasional (UU RI Nomor 14 Tahun 2005 tentang Guru dan Dosen Bab 1 Pasal 1 ayat 1). Slameto menjelaskan bahwa salah satu syarat pembelajaran yang efektif adalah guru harus mempunyai variasi dalam mengajar, baik media maupun model serta memiliki pengelolaan kelas yang baik (2013:92-95).

Penggunaan media pembelajaran memiliki banyak manfaat dalam proses belajar. Namun, fakta di lapangan yang ditemukan berdasarkan pra penelitian di SD Negeri 03 Bawu Jepara pada kelas II menunjukkan bahwa tidak ada media selain buku guru dan buku siswa yang digunakan pada pembelajaran SBdP. Dalam Permendikbud No 21 Tahun 2016 muatan SBdP memiliki ruang lingkup, meliputi seni rupa, seni musik, seni tari, prakarya dan warisan budaya. Hasil observasi menunjukkan bahwa siswa kelas II SD Negeri 03 Bawu Jepara memiliki ketuntasaan hasil belajar yang berbeda-beda diantara ketuntasan siswa dalam bidang seni rupa $68,3 \%$, dalam bidang seni musik $58,5 \%$ dan dalam bidang seni tari $34,1 \%$. Dari ketiga ruang lingkup muatan SBdP tersebut, pembelajaran seni tari termasuk kategori paling rendah. Hal ini diartikan bahwa pembelajaran SBdP dalam materi seni tari masih memprihatinkan dan membutuhkan upaya peningkatan hasil belajar.

Dari hasil observasi siswa banyak yang tidak antusias dengan pembelajaran seni tari apalagi dengan pembelajaran yang sekedar melihat contoh dari buku siswa. Pemanfaatan media yang berkaitan dengan teknologi juga belum dilakukan. Hal ini dikarenakan terbatasnya jumlah fasilitas seperti laptop, Liquid Crystal Display (LCD), Proyektor dan pengeras suara (speaker). Serta minimnya kemampuan guru dalam menggunakan fasilitas tersebut. Sehingga dibutuhkan upaya peningkatan hasil belajar siswa melalui penggunaan media pembelajaran yang tepat untuk mengantisipasi permasalahan ini.
Di kelas II SD Negeri 03 Bawu Jepara siswa kesulitan untuk memahami fenomena yang terjadi di lingkungan masyarakat dan alam sekitarnya. Siswa kesulitan menirukan gerak keseharian dan alam. Gerak ini termasuk gerak tiruan karena siswa menirukan gerak kegiatan sehari-hari dan bendabenda/peristiwa alam di sekitar. Seperti menirukan gerak benda, aktivitas sehari-hari, hewan, tumbuhan maupun alam. Hal ini terjadi dikarenakan pembelajaran yang dilakukan selalu di dalam ruangan. Padahal dengan pembelajaran di luar kelas siswa mampu memahami gerak-gerak alam secara langsung, dapat juga mengurangi rasa jenuh, bosan siswa, dan dapat membuat siswa senang tertarik terhadap pelajaran dan lingkungan sekitarnya.

Berdasarkan data dokumen menunjukkan bahwa Standar Kompetensi Lulusan KD gerak keseharian dan alam dalam tari Tema 2 Subtema 2 pembelajaran 1 belum tercapai sepenuhnya. Siswa yang mendapatkan nilai dibawah Kriteria Ketuntasan Minimal (KKM) ada 27 anak. Dengan nilai terendah 25 dan nilai tertinggi 90. Hasil tersebut menunjukkan bahwa secara klasikal 65,8 \% (27 siswa) belum mencapai KKM dan 34,1 \% (14 siswa) diantaranya telah mencapai KKM yang telah ditentukan yaitu 68 .

Peneliti akan mengembangkan media kartu kuartet DIKDA berbasis outdoor learning. Kegiatan pembelajaran yang dapat kontak langsung dengan lingkungan sekitar dan alam. Menurut Adelia Vera (2012:17) menyatakan Outdoor Learning yaitu suatu kegiatan yang melibatkan alam secara langsung untuk dijadikan sebagai sumber belajar. Apalagi materi yang diajarkan berkaitan dengan gerak keseharian dan alam, tentu banyak gerakan-gerakan yang dilakukan dapat ditemui langsung didalam proses pembelajaran outdoor learning tersebut.

Oleh karena itu, peneliti melakukan penelitian dan pengembangan dengan judul "Pengembangan Media kartu kuartet DIKDA Seni Tari berbasis Outdoor Learning pada Muatan SBdP untuk Meningkatkan Kemampuan Motorik Siswa Kelas II SDN 03 Bawu Jepara" dengan tujuan untuk mengembangkan, mengetahui hasil kelayakan serta menguji keefektifan produk media pembelajaran yang dikembangkan.

\section{METODE PENELITIAN}

Penelitian ini merupakan penelitian Research and Development, yaitu penelitian yang digunakan untuk menghasilkan produk tertentu dan menguji keefektifan produk tersebut (Sugiyono, 2016: 407). Langkah- 
langkah penelitian dan pengembangan menurut Sugiyono disajikan dalam diagram berikut ini.

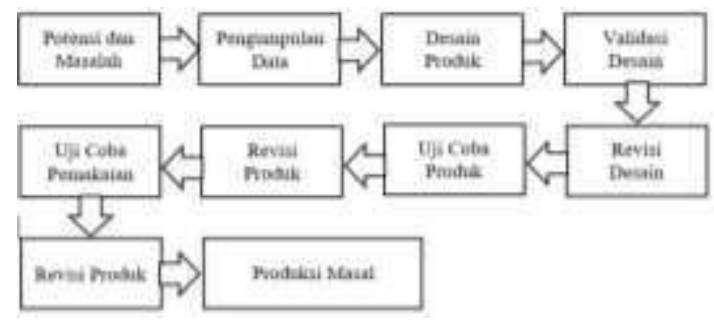

Bagan 1.Langkah-Langkah Metode R\&D (Sugiyono 2016:409)

Prosedur dalam penelitian ini meliputi: (1) potensi dan masalah melalui pra penelitian yaitu wawancara, observasi dan studi dokumen; (2) pengumpulan data berupa analisis kebutuhan guru dan siswa; (3) desain produk kartu kuartet DIKDA seni tari; (4) validasi desain oleh ahli materi dan media; (5) revisi desain kartu kuartet DIKDA seni tari sesuai saran ahli; (6) uji coba produk kartu kuartet DIKDA seni tari; (7) uji coba pemakaian; (8) produk akhir media kartu kuartet DIKDA seni tari berbasis outdoor learning materi gerak keseharian dan alam bagi siswa kelas II Sekolah Dasar.

Subjek penelitian ini adalah siswa kelas II SD Negeri 03 Baru berjumlah 41 siswa. Subjek penelitian berperan dalam pengumpulan data, pelaksanaan uji coba baik skala kecil maupun besar, serta tanggapan atas media kartu kuartet DIKDA seni tari yang dikembangkan peneliti. Uji coba skala kecil dilakukan pada sembilan siswa dengan teknik purposive sampling, sedangkan uji coba skala besar melibatkan seluruh subjek penelitian dengan teknik sampling jenuh. Desain rancangan yang digunakan adalah pretestposttest design dengan membandingkan hasil antara sebelum dan sesudah menggunakan media pembelajaran. Variabel yang diteliti meliputi media kartu kuartet DIKDA seni tari berbasis outdoor learning sebagai variabel bebas dan hasil belajar psikomotorik SBdP materi gerak keseharian dan alam sebagai variabel terikat.

Teknik pengumpulan data yang digunakan adalah teknik tes unjuk kerja menggunakan rubrik penilaian, serta teknik nontes berupa instrumen wawancara, angket, studi dokumen dan observasi. Sedangkan teknik analisis data meliputi analisis data produk berupa analisis kelayakan media kartu kuartet DIKDA seni tari serta tanggapan guru dan siswa; analisis data awal menggunakan uji normalitas Lilieforse (Sudjana, 2005: 466); dan analisis data akhir meliputi t-test dan $\neg$ n-gain (Lestari dan Yudhanegara, 2015:235).
Siti Eva Ariyanti / Joyful Learning Journal 9 (2) 2020

\section{HASIL PENELITIAN DAN PEMBAHASAN}

\section{Pengembangan Media Kartu Kuartet DIKDA Seni Tari Berbasis Outdoor Learning}

Pengembangan media kartu kuartet DIKDA seni tari berbasis Outdoor Learning dilakukan melalui tahap potensi dan masalah, pengumpulan data, desain produk, validasi desain produk, revisi desain produk, uji coba produk, revisi produk, uji coba pemakaian, dan produk akhir. Berdasarkan hasil analisis angket kebutuhan media pembelajaran yang diberikan kepada guru dan siswa menunjukkan bahwa diperlukan variasi media pembelajaran yang menarik dan menyenangkan bagi siswa. Salah satu media yang dapat dikembangkan adalah media kartu kuartet DIKDA seni tari berbasis outdoor learning.

Pada tahap desain produk, peneliti menyusun draft produk kartu kuartet DIKDA seni tari berbasis outdoor learning dengan hasil analisis angket kebutuhan guru dan angket kebutuhan siswa. Desain perancangan tersebut diaplikasikan kedalam pembuatan prototype. Setelah pembuatan prototype, media direalisasikan dalam bentuk media cetak. Tahap revisi kartu kuartet DIKDA seni tari berbasis outdoor learning, peneliti melakukan revisi desain sesuai saran masing-masing ahli, yaitu ahli media, ahli materi, dan ahli bahasa dan sudah divalidasi oleh tim ahli tersebut dengan mengisi angket penilaian kelayakan media, materi, dan bahasa.

Media yang akan diterapkan pada siswa adalah media kartu kuartet. Bernama Kartu Kuartet DIKDA, singkatan dari Dinamika Simulasi Keseharian dan Alam. Berukuran 9 x $12 \mathrm{~cm}$. Cover box kuartet DIKDA dicetak dengan kertas art carton 310 gram dan kertas art carton 260 gram untuk masing-masing kartu kuartet DIKDA. Media kartu kuartet DIKDA seni tari berbasis outdoor learning berisi materi gerak keseharian dan alam dengan berjumlah 10 tema diantaranya tema keseharian: 1) bermain, 2) aktivitas nelayan, 3) berkebun, 4) aktivitas rumah dan 5) hewan. Serta tema alam meliputi 1) bunga, 2) pepohonan, 3) angin, 4) ombak laut dan 5) air. Selain himpunan $10 \mathrm{kartu}$ yang masing-masing memiliki 4 subtema tersebut terdapat juga KI, $\mathrm{KD}$, indikator, panduan untuk guru dan panduan untuk siswa.

Media yang dikembangkan dapat memberikan pembelajaran yang menarik dan menyenangkan. Hal tersebut sesuai dengan pendapat Hamalik (dalam Arsyad, 2014: 19) mengemukakan bahwa pemakaian media pembelajaran dalam proses belajar mengajar dapat membangkitkan keinginan dan minat yang baru, membangkitkan motivasi dan rangsangan kegiatan belajar, dan bahkan membawa pengaruh-pengaruh psikologis 
terhadap anak. Dengan kata lain, mengandung materi instruksional di lingkungan siswa yang dapat merangsang siswa untuk belajar.

Penelitian yang relevan dilakukan oleh Putrika Rahajeng Sidowati dalam E-Jurnal Prodi Teknologi Pendidikan (Volume. VI, No. 3, 2017) dari Universitas Negeri Yogyakarta, berjudul "Pengembangan Media Kartu Kuartet Satuan Waktu untuk Siswa Sekolah Dasar". Penelitian pengembangan ini bertujuan untuk menghasilkan media kartu kuartet satuan waktu matematika (Kuantum) yang layak untuk pembelajaran matematika kelas V di SD Negeri Sarikarya Yogyakarta. Hasil penelitian menunjukan bahwa media permainan kartu kuartet efektif dalam meningkatkan hasil belajar.

\section{Hasil Kelayakan Media Kartu Kuartet DIKDA Seni Tari Berbasis Outdoor Learning}

Media kartu kuartet DIKDA seni tari berbasis outdoor learning pada pembelajaran SBdP perlu diuji kelayakannya oleh pakar ahli. Terdapat tiga pakar ahli yang menganalisis media kartu kuartet DIKDA seni tari berbasis outdoor learning. Hal ini bertujuan untuk mendapatkan penilaian media yang layak digunakan untuk siswa. Pada penelitian ini, instrumen penilaian kelayakan media untuk validator dikembangkan yang kemudian divalidasi oleh dosen pembimbing. Selanjutnya, isntrumen validasi media tersebut dapat digunakan sebagai acuan kelayakan media tersebut.

Validasi kelayakan materi dilakukan oleh Dr. Deasylina da Ary, S. Pd., M. Sn. dosen Prodi Pendidikan Guru Sekolah Dasar, Fakultas Ilmu Pendidikan, Universitas Negeri Semarang. Validasi kelayakan materi bertujuan untuk mengetahui kesesuaian materi yang dibutuhkan oleh siswa dengan konten media. Validasi kelayakan ahli media dilakukan oleh Sony Zulfikasari, S.Pd,. M.Pd. dosen Prodi Teknologi Pendidikan, Fakultas Ilmu Pendidikan, Universitas Negeri Semarang. Validasi kelayakan ahli media ini bertujuan untuk mengetahui kualitas media pembelajaran yang dikembangkan. Serta validasi kelayakan ahli bahasa dilakukan oleh Dr. Wagiran, M.Hum. dosen Bahasa dan Sastra Indonesia, Fakultas Bahasa dan Seni, Universitas Negeri Semarang. Validasi kelayakan ahli bahasa bertujuan untuk mengetahui aturan penggunaan bahasa pada media pembelajaran yang dikembangkan.

Aspek materi berkaitan dengan empat indicator yaitu relevan dengan $\mathrm{KD}$, Indikator, dan tujuan pembelajaran; memuat materi gerak keseharian dan alam; disajikan dengan jelas, logis, dan runtut; sesuai dengan karakterisktik dan tingkat perkembangan siswa. Hasil validasi kelayakan materi Media kartu kuartet DIKDA
Siti Eva Ariyanti /Joyful Learning Journal 9 (2) 2020 seni tari berbasis outdoor learning diperoleh persentase penilaian kelayakan materi sebesar 96,88\% dengan kriteria sangat layak. Lembar penilaian media terdiri dari aspek kerapian media, aspek kualitas gambar dan warna, aspek kesesuaian media dengan materi, aspek kualitas bahan, aspek kecocokan media dengan sasaran, aspek orientasi pada siswa, dan aspek kepraktisan media. Hasil kelayakan ahli Media kartu kuartet DIKDA seni tari berbasis outdoor learning diperoleh persentase penilaian sebesar $96,88 \%$ dengan kriteria sangat layak. Serta lembar penilaian ahli bahasa terdiri dari aspek komunikatif bahasa yang meliputi bahasa yang ada pada media yang mudah dipahami, kalimat yang digunakan memperjelas gambar, penulisan kalimat pada media, kebenaran penggunaan tanda baca, kebenaran pemakaian huruf pada media. Sedangkan aspek kualitas motivasi meliputi bahasa yang digunakan media memotivasi siswa. Hasil kelayakan bahasa media kartu kuartet DIKDA seni tari berbasis outdoor learning diperoleh persentase penilaian sebesar 93,75\% dengan kriteria layak dengan revisi.

Berdasarkan hasil validasi ahli secara keseluruhan, Media kartu kuartet DIKDA seni tari berbasis outdoor learning memenuhi kriteria layak sebagai media pembelajaran, sehingga layak diuji cobakan pada siswa.

\section{Hasil Keefektifan Media Kartu Kuartet DIKDA Berbasis Outdoor Learning}

Uji keefektifan Media kartu kuartet DIKDA seni tari berbasis outdoor learning dilakukan untuk mengetahui keefektifan media dalam meningkatkan hasil belajar Psikomotorik siswa yang didapat dari hasil nilai pretest dan posttest. Nilai pretest didapat sebelum siswa menggunakan Media kartu kuartet DIKDA seni tari berbasis outdoor learning. Sedangkan nilai posttest didapat setelah dilakukan pembelajaran menggunakan Media kartu kuartet DIKDA seni tari berbasis outdoor learning.

Hasil pada uji kelompok kecil memiliki nilai pretest siswa dengan rata-rata sebesar 57,56. Nilai tertinggi 75 dan nilai terendah adalah 42. Dengan KKM 68, presentase ketuntasan yang diperoleh pada saat pretest adalah 11\%. Sedangkan hasil belajar siswa pada pembelajaran posttest mendapat rata-rata 81,44 . Nilai tertinggi yang diperoleh pada saat posttest adalah 92 dan nilai terendah adalah 67. Dengan KKM 68, presentase ketuntatasan yang diperoleh pada saat pembelajaran posttest adalah $89 \%$.

Hasil pada uji kelompok besar memiliki nilai pretest siswa kelas II dengan rata-rata 63,81 . Nilai tertinggi yang diperoleh pada saat pretest adalah 83 dan nilai terendah adalah 42 dengan presentase ketuntasan yang diperoleh saat pretest $28 \%$. Sedangkan jumlah nilai saat 
posttest, hasil belajar siswa kelas II menggunakan Media kartu kuartet DIKDA seni tari berbasis outdoor learning dengan ratarata 80,19. Nilai tertinggi yang diperoleh pada saat posttest adalah 92 dan nilai terendah adalah 58 dengan presentase ketuntasan yang diperoleh saat posttest adalah 87,5\%.

Dari hasil rata-rata nilai skala kecil dapat diketahui adanya peningkatan nilai ratarata pretest sebesar 57,56 dan nilai rata-rata posttest sebesar 81,44 dengan N-Gain sebesar 0,567 kriteria sedang. Pada kelompok besar diketahui bahwa hasil pretest sebelum menggunakan media memperoleh rata-rata sebesar 63,81 . Sedangkan nilai posttest setelah menggunakan media memperoleh rata-rata sebesar 80,19. Dari hasil rata-rata nilai tersebut dapat diketahui adanya peningkatan nilai pretest dan posttest dengan N-Gain sebesar 0,466 kriteria sedang.

\section{SIMPULAN}

Berdasarkan hasil analisis data dan pembahasan dapat diambil sipulan bahwa peneliti mengembangkan media kartu kuartet DIKDA seni tari berbasis outdoor learning Kartu kuartet DIKDA memiliki kepanjangan Dinamika Simulasi Keseharian dan Alam yang memiliki 5 tema keseharian dan 5 tema alam dengan masing-masing tema terdapat 4 kartu sehingga berjumlah 40 kartu, terdapat tambahan kartu KI, KD, indikator, panduan untuk guru dan panduan untuk siswa. Media kartu kuartet DIKDA seni tari berbasis outdoor learning memenuhi kriteria sangat layak dari ahli media, ahli materi dan ahli bahasa. Serta dari hasil tanggapan siswa mencapai 100\% dan dari guru 92\% untuk skala kecil dan tanggapan siswa $97,9 \%$ dan dari guru $100 \%$ pada skala besar. Media kartu kuartet DIKDA seni tari berbasis outdoor learning efektif dibuktikan dengan peningkatan pada skala kecil rata-rata nilai pre-test 57,56 menjadi 81,44 pada ratarata nilai pre-test atau memiliki peningkatan $\mathrm{N}$ gain sebesar 0,567 , pada skala besar rata-rata nilai pre-test 63,81 menjadi 80,19 pada ratarata nilai post-test atau memiliki peningkatan $\mathrm{N}$-gain sebesar 0,466.

\section{UCAPAN TERIMAKASIH}

Penulis mengucapkan terima kasih kepada (1) Tuhan Yang Maha Esa; (2) Kedua orang tua yang selalu memberikan dukungan dan doa; (3) Dr. Deasylina da Ary, S.Pd., M.Sn, selaku dosen pembimbing yang telah memberikan bimbingan, petunjuk serta semangat dalam menyusun manuskrip; (4) Putri Yanuarita S, S. Pd., M. Sn. dan Dr. Deni Setiawan, S. Sn., M.Hum., selaku mitra bestari yang telah memberikan bimbingan dan masukkan untuk kesempurnaan manuskrip ini;
Siti Eva Ariyanti /Joyful Learning Journal 9 (2) 2020 (5) Arif Widagdo, S. Pd., M. Pd selaku dosen penyunting abstrak bahasa Inggris yang membantu menyempurnakan manuskrip ini.

\section{DAFTAR PUSTAKA}

Ahmad, Syarwan. 2014. Problematika Kurikulum 2013 Dan Kepemimpinan Instruksional Kepala Sekolah. Jurnal Pencerahan. 8 (2): 99.

Amini R \& Munandar A. (2010). Pengaruh Model Pembelajaran Pendidikan Lingkungan berbasis Outdoor terhadap Penguasaan Konsep Pendidikan Lingkungan bagi Calon Guru Sekolah Dasar. Jurnal Penelitian Pendidikan. 11(1): 15.

Arsyad, Azhar. 2014. Media Pembelajaran. Jakarta: Rajawali Pers.

Ayriza, Yulia, dkk. 2017. Quartet Cards as The Media of Career Exploration for Lower-grade Primary School Student.RED (Research and Evaluation in Education). 3(2) :180.

Darnius, Said. 2016. Identifikasi Kesulitan Guru Dalam Mengimplementasikan Kurikulum 2013 dengan Pendekatan Saintifik Di Kelas Tinggi Gugus Mangga Kecamatan Jaya Baru Banda Aceh. JURNAL PESONA DASAR. 2 (4): 41 .

Husamah. 2013. Pembelajaran Luar kelas (Out Door Learning). Jakarta: Rineka Cipta.

Indriyaningsih, Yuliana. 2013. Dance activity model to form students' character in elementary school. INSANIA 18 (2): 293.

Lestari, Karunia Eka \& Yudhanegara, Muhammad Ridwan. 2015. Penelitian Pendidikan Matematika. Bandung IKAPI.

Nugroho, A A. \& Hanik, N R. (2019). Implementation of Outdoor Learning to Improve Students Cognitive Learning Outcomes on High Plant Systematics Course. Jurnal BIOEDUKASI. 9 (1): 43.

Peraturan Menteri Pendidikan Dan Kebudayaan Republik Indonesia No 21 Tahun 2016 Tentang Standar Isi Pendidikan Dasar Dan Menengah.

Prasetya, Yulia Eka \& Khabibah, siti. (2016). Pengembangan Media Permainan Kartu Kuartet dalam Pembelajaran Matematika pada Materi Pokok Segitiga 
dan Segiempat. Jurnal Ilmiah Pendidikan Matematika 1 (5): 95.

Rachmawati, N., Setyowati, D L., \& Rusilowatin, N. (2013). Pengembangan Perangkat Pembelajaran IPS Terpadu berbasis Outdoor Learning. Jurnal of Primary Educational 2 (2): 80.

Sidowati, Putrika Rahajeng.(2017). Pengembangan Media Kartu Kuartet Satuan Waktu untuk Siswa Sekolah Dasar. E-Jurnal Prodi Teknologi Pendidikan 4 (3).

Slameto. 2013. Belajar \& Faktor-Faktor Yang Mempengaruhi. Jakarta: Rineka Cipta
Siti Eva Ariyanti / Joyful Learning Journal 9 (2) 2020

Sudjana. 2005. Metode Statistika. Bandung: Tarsito

Sugiyono, 2016. Metode Penelitian Pendidikan. Bandung: Alfabeta.

Undang-Undang Republik Indonesia Nomor 14 Tahun 2005 Tentang Guru Dan Dosen.

Vera, A. 2012. Metode Mengajar Abak Diluar Kelas (Out Door Study). Yogyakarta: Diva Press.

Wahyuningsih A. N dan Kustiarini. (2018). Pengembangan Perangkat Pembelajaran Menggambar berbasis Outdoor Learning bagi Siswa Sekolah Dasar . Jurnal Riset $\begin{array}{llll}\text { Pendidikan } & \text { Dasar } 1 & \text { (2): } 8\end{array}$ 